\title{
OPEN Author Correction: Air pollution- derived particulate matter dysregulates hepatic Krebs cycle, glucose and lipid metabolism in mice
}

\author{
Hermes Reyes-caballero $\mathbb{D}^{1}$, Xiaoquan Rao, Qiushi Sun, Marc O. Warmoes, Penghui Lin (D,

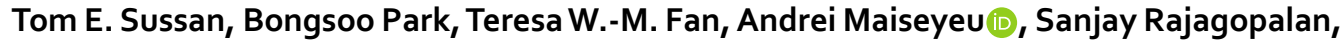 \\ Geoffrey D. Girnun \& Shyam Biswal
}

Correction to: Scientific Reports https://doi.org/10.1038/s41598-019-53716-y, published online 22 November 2019

The original version of this Article contained an error in the name of the author Penghui Lin which was incorrectly given as Lin Penghui.

This error has now been corrected in the PDF and HTML versions of the Article, and in the accompanying Supplementary Information file.

(i) Open Access This article is licensed under a Creative Commons Attribution 4.0 International License, which permits use, sharing, adaptation, distribution and reproduction in any medium or format, as long as you give appropriate credit to the original author(s) and the source, provide a link to the Creative Commons license, and indicate if changes were made. The images or other third party material in this article are included in the article's Creative Commons license, unless indicated otherwise in a credit line to the material. If material is not included in the article's Creative Commons license and your intended use is not permitted by statutory regulation or exceeds the permitted use, you will need to obtain permission directly from the copyright holder. To view a copy of this license, visit http://creativecommons.org/licenses/by/4.0/.

(C) The Author(s) 2020 